\title{
Understanding the Molecular Genetics of Basal Cell Carcinoma
}

\author{
Cristina Pellegrini ${ }^{+}$(1), Maria Giovanna Maturo ${ }^{\dagger}$, Lucia Di Nardo (iD, Valeria Ciciarelli, \\ Carlota Gutiérrez García-Rodrigo and Maria Concetta Fargnoli * \\ Department of Dermatology, Department of Biotechnological and Applied Clinical Sciences, University of \\ L'Aquila, 67100 L'Aquila, Italy; cristina.pellegrini@cc.univaq.it (C.P.); \\ mariagiovanna.maturo@graduate.univaq.it (M.G.M.); luciadinardo@hotmail.it (L.D.N.); \\ valeria.ciciarelli@hotmail.it (V.C.); carlota.gutierrez.gr@gmail.com (C.G.G.-R.) \\ * Correspondence: mariaconcetta.fargnoli@univaq.it; Tel.: +39-0862-368519; Fax: +39-0862-433433 \\ † The authors contributed equally to this work.
}

Received: 17 October 2017; Accepted: 21 November 2017; Published: 22 November 2017

\begin{abstract}
Basal cell carcinoma (BCC) is the most common human cancer and represents a growing public health care problem. Several tumor suppressor genes and proto-oncogenes have been implicated in BCC pathogenesis, including the key components of the Hedgehog pathway, PTCH1 and SMO, the TP53 tumor suppressor, and members of the RAS proto-oncogene family. Aberrant activation of the Hedgehog pathway represents the molecular driver in basal cell carcinoma pathogenesis, with the majority of BCCs carrying somatic point mutations, mainly ultraviolet (UV)-induced, and/or copy-loss of heterozygosis in the PTCH1 gene. Recent advances in sequencing technology allowed genome-scale approaches to mutation discovery, identifying new genes and pathways potentially involved in BCC carcinogenesis. Mutational and functional analysis suggested PTPN14 and LATS1, both effectors of the Hippo-YAP pathway, and MYCN as new BCC-associated genes. In addition, emerging reports identified frequent non-coding mutations within the regulatory promoter sequences of the TERT and DPH3-OXNAD1 genes. Thus, it is clear that a more complex genetic network of cancer-associated genes than previously hypothesized is involved in BCC carcinogenesis, with a potential impact on the development of new molecular targeted therapies. This article reviews established knowledge and new hypotheses regarding the molecular genetics of BCC pathogenesis.
\end{abstract}

Keywords: basal cell carcinoma; molecular genetics; PTCH1; TP53; MYCN; PTPN14; LATS1; TERT promoter; $D P H 3$ promoter

\section{Introduction}

Basal cell carcinoma (BCC) is the most common malignant neoplasm in fair-skinned individuals, and accounts for about two-thirds of all skin cancers in Caucasians [1]. The incidence reached 2.75 million cases worldwide [2], representing a growing public health care problem. BCC rarely metastasizes or causes death, but it can result in extensive morbidity through local invasion and tissue destruction [1]. The appearance of BCC is strongly associated with exposure to ultraviolet (UV) radiations: tumors develop primarily on the sun-exposed skin of elderly individuals with fair skin type; they are rarely found on palmo-plantar surfaces or in children, and never appear on the mucosa. Men are more frequently affected than women, usually after the age of 50 . However, a remarkable increase in the incidence of BCC has been recently observed in young women, probably due to a higher use of tanning beds for cosmetic purposes and to a closer attention to their appearance and the health of their skin [3]. Younger individuals develop BCC predominantly located on the trunk and limbs, caused by increasing affluence and consequent leisure-related, episodic sun exposure [4]. 
Additionally, established risk factors of BCC include ionizing radiations, arsenic ingestion, and immune suppression [5].

Evidences of genetic alterations in BCC pathogenesis derive from studies of patients with a hereditary predisposition syndrome, known as basal cell nevus syndrome (BCNS) or Gorlin syndrome. As early as 1894, Jarisch and White first described patients with clinical features of the autosomally inherited BCNS syndrome [6,7] which was later characterized in detail by Gorlin and Goltz [8]. BCNS patients typically develop multiple BCCs starting at a young age and are prone to develop other tumors including medulloblastomas. Using family-based linkage studies of kindreds with BCNS, the locus carrying the causative mutant gene was mapped to human chromosome 9q22 and then to the Patched 1 (PTCH1) gene [9]. PTCH1 is a transmembrane receptor that acts negatively in the hedgehog $(\mathrm{HH})$ signaling pathway. After the identification of $P T C H 1$ as the BCNS disease gene $[10,11]$, PTCH1 and other components of the HH pathway, as smoothened (SMO) and glioma-associated oncogene (GLI), were investigated in sporadic BCC [12-14]. These pioneering studies demonstrated that loss-of-function mutations of PTCH1 and/or gain-of-function mutations of SMO were implicated in the pathogenesis of this disease. In subsequent reports, including a high number of sporadic BCCs, molecular alterations of the HH pathway components were identified in about $90 \%$ of the cases [12,14-19]. Therefore, the aberrant HH signaling activation was defined as a prerequisite for the development of BCC both for the inherited (Gorlin's syndrome) and for the sporadic forms of the disease.

Beyond $\mathrm{HH}$ signaling, other tumor suppressor genes and proto-oncogenes have been implicated in the pathogenesis of BCC, including the TP53 tumor suppressor gene and members of the RAS proto-oncogene family [17-21]. In a recent study including 293 BCC tumors, the driver pivotal role of PTCH1, TP53, and SMO has been confirmed; however, $85 \%$ of BCC also harbored additional driver mutations in other cancer-related genes, such as MYCN, PPP6C, PTPN14, STK19, and LATS1 [22]. Finally, emerging reports have identified somatic mutations within regulatory sequences as the promoters of the telomerase reverse transcriptase (TERT) gene and of the diphthamide biosynthesis 3 (DPH3) gene [23-26].

Of note, the mutational pattern of genes involved in BCC tumorigenesis is consistent with UV-induced DNA damage, since genes harbor "UV signature" mutations [27]. Solar radiation (UVB and UVA) can mutagenize DNA, producing UV landmark $C$ to $\mathrm{T}$ or CC to TT transversions via cyclobutane dimers and pyrimidine(6-4)pyrimidine photoproducts [28]. The transformation of the keratinocytes occurs when these mutations affect the function of multiple oncogenes, tumor-suppressor genes and important housekeeping genes, leading to an unregulated cell cycle [29].

This review aims to provide an overview of the molecular genetics of BCC pathogenesis, describing the mutational events occurring both in established and recently discovered BCC driver genes.

\section{Established BCC-Associated Genes}

\subsection{HH Pathway Genes}

$\mathrm{HH}$ is a highly-conserved development pathway involved in organogenesis, stem cell maintenance, tissue repair, and regeneration. In the skin, the $\mathrm{HH}$ pathway is responsible for maintaining the stem cell population and for controlling development of hair follicles and sebaceous glands [30]. Aberrant $\mathrm{HH}$ pathway activation controls multiple aspects of tumorigenesis including initiation, progression, and relapse, at least in part, by driving a cancer stem cell phenotype [31].

The canonical HH pathway contains several key components, including the $\mathrm{HH}$ ligands as sonic $\mathrm{HH}$, Indian $\mathrm{HH}$, and Desert $\mathrm{HH}$, the transmembrane receptor proteins $\mathrm{PTCH} 1$ and $\mathrm{PTCH} 2$, the $\mathrm{G}$ protein coupled receptor-like protein $S M O$, and the GLI transcription factors 1, 2, and 3 (GLI1, GLI2, and GLI3) [32] (Figure 1). HH signaling transduction depends on the primary cilium structure, a highly specialized microtubule-based organelle that protrudes from the plasma membrane in almost all cell types and acts as a sensor for extracellular signals $[33,34]$. The pathway is activated when $\mathrm{HH}$ 
ligands bind PTCH1 to relieve PTCH-mediated SMO inhibition at the base of primary cilium [35]. $S M O$ then translocates to the cilium, driving a signaling cascade that leads to release of the GLI proteins, sequestered in the cytoplasm by several proteins, including the suppressor of fused (SUFU). Then, GLI transcription factors translocate into the nucleus and activate transcription of context-specific genes regulating self-renewal, cell fate, survival, and angiogenesis. In addition, GLI1 establishes a feedback loop that auto-regulates $\mathrm{HH}$ signaling through PTCH1 modulation [36]. Mutations at any level of the HH signaling pathway (e.g., PTCH1, SMO, and SUFU) will result in an increased expression of GLI1.

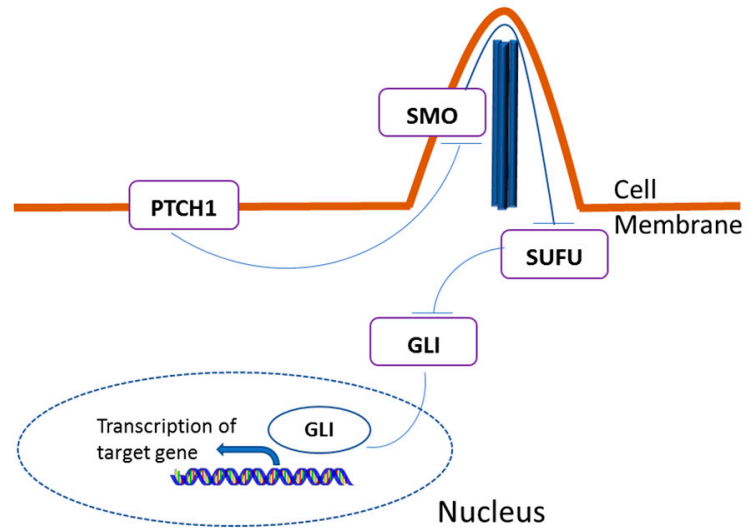

(a)

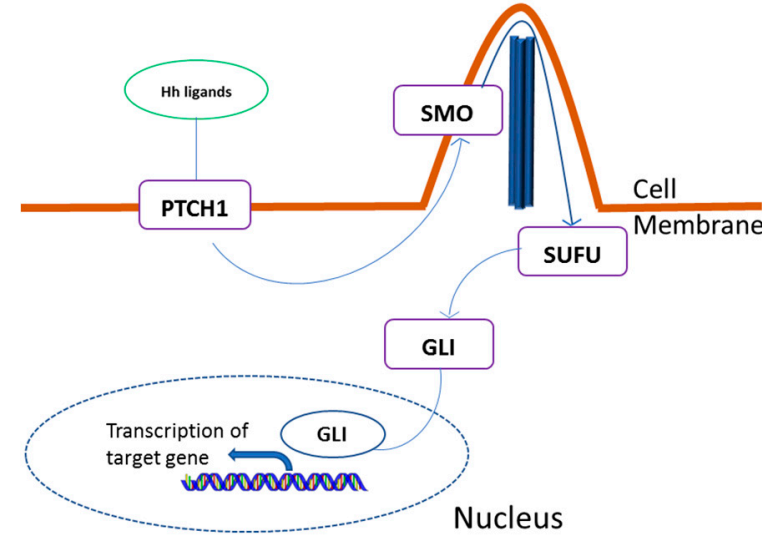

(b)

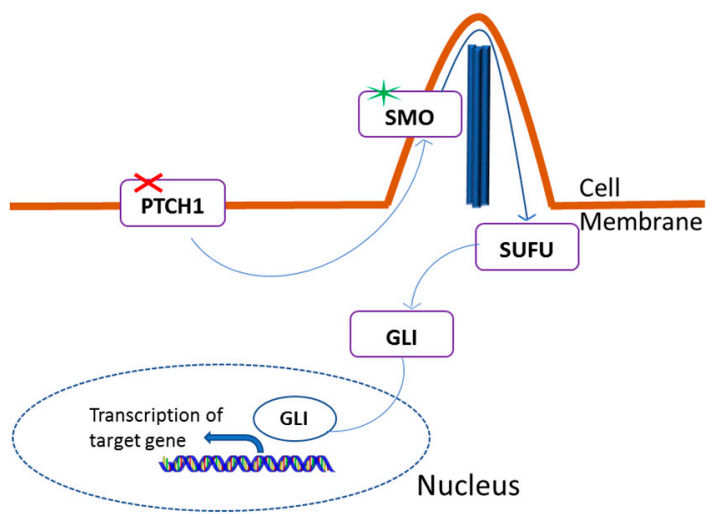

(c)

Figure 1. Physiologic and oncogenic Hedgehog signaling. (a) In the absence of HH ligands, PTCH1 constitutively represses $S M O$, blocking the HH signal transduction; (b) The family of extracellular $\mathrm{HH}$ ligands binds to $P T C H 1$, de-represses $S M O$ thereby allowing its translocation on the tip of the primary cilium. SMO sends signals through a series of interacting proteins, including SUFU, resulting in activation of the downstream GLI family of transcription factors; (c) Loss of function of PTCH1 (red cross) or activating mutations of $S M O$ (blue asterisk) induces $\mathrm{HH}$ pathway in the absence of $\mathrm{HH}$ ligands. HH; Hedgehog; PTCH1; Patched Homolog 1; SMO; SMOothened; SUFU; suppressor of fused; GLI; glioma-associated oncogene.

In addition to the abovementioned signaling pathway, there is a non-canonical $\mathrm{HH}$ cascade resulting in the activation of GLI transcription factors independent of HH ligands or PTCH1/SMO. GLI activity has been shown to be regulated positively by KRAS, TGF- $\beta$, PI3K-AKT, and PKC- $\alpha$ [37-43], and negatively by p53, PKA, and PKC- $\delta$ [43-46].

Upregulation of $\mathrm{HH}$ signaling represents the most significant pathogenic event in BCC. More than 90\% of BCCs show a loss of PTCH1 function by inactivating PTCH1 mutations, as well as by aberrant activation of SMO through activating SMO mutations [12,14-19,47-50].

The PTCH1 gene has been mapped to 9 q22.3 and consists of 23 exons spanning approximately $74 \mathrm{~kb}$ encoding a 1447 transmembrane glycoprotein. The sequence suggests that PTCH1 is a 
transmembrane protein with 12-membrane spanning domains and 2 large extracellular loops. The inactivation of PTCH1 in BCCs may be a necessary, if not sufficient, event for carcinogenesis. Sporadic BCCs have been reported to carry inactivating point mutations, copy loss of heterozygosity (LOH), and copy-neutral LOH (due to uniparental disomy) in PTCH1 [19,49,50]. PTCH1 somatic mutations range between $11 \%$ and $75 \%$ (Table 1) $[11,12,15,18,19,22,48-52]$ and are represented by non-synonymous mutations with a predominance of nonsense and splice site mutations throughout the entire length of the PTCH1 gene, without evidence for a hot-spot region. About half of these mutations contains the "UV-signature" C-T and tandem CC-TT transitions [17-19,22,48,51,53]; however, the UV radiation origin of $\mathrm{PTCH} 1$ mutations is controversial, since other factors, such as oxidative stress, have been implicated in the mutagenesis of this gene $[12,18,22,54]$. Besides point mutations, somatic copy number aberrations (SCNAs) of PTCH1 have been frequently reported in BCC [12,15,18,19,22,48-52]. $\mathrm{LOH}$ of the PTCH1 allele is the most frequently identified SCNA in BCC and occurs in about $42-70 \%$ of the tumors due to loss of part of or the whole of $9 q$ chromosome arm $[19,55,56]$ (Table 1).

Table 1. Frequency of mutations and loss of heterozygosity (LOH) in cancer-related genes across published studies in basal cell carcinoma (BCC).

\begin{tabular}{|c|c|c|c|c|}
\hline Gene & Nr. of Samples Analyzed & Mutations (\%) & LOH (\%) & References \\
\hline \multirow{11}{*}{ PTCH1 } & 37 & 32.4 & 24.3 & [12] \\
\hline & 55 & - & 66.7 & [51] \\
\hline & $26^{a}$ & 11.8 & 38.2 & [15] \\
\hline & 24 & 54.2 & - & {$[11]$} \\
\hline & 15 & 40.0 & 53.3 & [18] \\
\hline & 31 & 54.8 & 43.5 & {$[52]$} \\
\hline & 42 & 66.7 & 52.6 & {$[19]^{*}$} \\
\hline & $14^{\mathrm{b}}$ & 64.3 & 92.8 & [49] \\
\hline & $12^{b}$ & 8.3 & 40.0 & {$[50]$} \\
\hline & 12 & 75.0 & 41.7 & [48] \\
\hline & $293^{c}$ & 73.0 & 55.0 & {$[22] *$} \\
\hline \multirow{12}{*}{ TP53 } & 14 & 50.0 & na & [57] \\
\hline & $18^{\mathrm{d}}$ & 61.1 & 5.5 & [51] \\
\hline & 27 & 56.0 & na & [58] \\
\hline & 20 & 35.0 & na & [59] \\
\hline & 24 & 45.8 & na & [11] \\
\hline & 15 & 33.0 & - & [18] \\
\hline & $50^{\mathrm{e}}$ & 66.0 & na & [60] \\
\hline & $98^{\mathrm{f}}$ & 37.7 & na & [60] \\
\hline & 42 & 40.5 & 7.9 & [48] \\
\hline & 30 & 20.0 & na & [61] \\
\hline & 12 & 66.7 & na & [19] \\
\hline & 293 & 61.0 & 17.0 & {$[22]^{*}$} \\
\hline \multirow{3}{*}{$S M O$} & 47 & 6.38 & na & [14] \\
\hline & 42 & 9.5 & na & [48] \\
\hline & 293 & 20.0 & na & {$[22] *$} \\
\hline \multirow{2}{*}{ SUFU } & 42 & 2.4 & na & [48] \\
\hline & 293 & 8.0 & 5.0 & {$[22] *$} \\
\hline \multirow{2}{*}{ NOTCH1 } & 12 & 50.0 & na & [19] * \\
\hline & 293 & 29.0 & 2.7 & {$[22] *$} \\
\hline \multirow{2}{*}{$\mathrm{NOTCH} 2$} & 12 & 66.7 & na & [19] * \\
\hline & 293 & 26.0 & na & [22] * \\
\hline LATS1 & 293 & 16.0 & 4.0 & {$[22] *$} \\
\hline LATS1 & 293 & 12.0 & 5.0 & [22] * \\
\hline РРР6С & 293 & 15.0 & 46.0 & [22] * \\
\hline STK19 & 293 & 10.0 & na & [22] * \\
\hline
\end{tabular}


Table 1. Cont.

\begin{tabular}{|c|c|c|c|c|}
\hline Gene & Nr. of Samples Analyzed & Mutations (\%) & LOH (\%) & References \\
\hline$M Y C N$ & 293 & 30.0 & na & {$[22] *$} \\
\hline ARID1A & 293 & 26.0 & 3.0 & {$[22] *$} \\
\hline PTPN14 & 293 & 22.0 & 5.0 & {$[22] *$} \\
\hline CASP8 & 293 & 11.0 & 3.0 & {$[22] *$} \\
\hline CSMD1 & 12 & 91.7 & na & {$[19]$ * } \\
\hline DPP10 & 12 & 75.0 & na & {$[19]$ * } \\
\hline CSMD2 & 12 & 66.7 & na & {$[19]$ * } \\
\hline CSMD3 & 12 & 58.3 & na & {$[19]$ * } \\
\hline PREX2 & 12 & 58.3 & na & {$[19]$ * } \\
\hline DCC & 12 & 50.0 & na & {$[19]$ * } \\
\hline GRIN2A & 12 & 50.0 & na & {$[19]$ * } \\
\hline \multirow{4}{*}{ TERT-promoter } & 32 & 56.2 & na & {$[23]$} \\
\hline & $42^{g}$ & 73.8 & na & {$[24]$} \\
\hline & $196^{\mathrm{h}}$ & 38.8 & na & [25] \\
\hline & 137 & 65.0 & na & [26] \\
\hline DPH3/OXNAD1 promoter & 137 & 41.6 & na & [26] \\
\hline \multicolumn{5}{|c|}{$\begin{array}{l}\text { a } 26 \text { sporadic basal cell carinomas (BCCs) and } 8 \text { BCCs from patients with Gorlin Syndrome; }{ }^{\mathrm{b}} 6 \text { sporadic BCCs and } \\
6 \text { BCC from patients with with Gorlin Syndrome; }{ }^{\mathrm{c}} 263 \text { sporadic BCCs and } 30 \text { BCCs from patients with Gorlin } \\
\text { Syndrome; }{ }^{\mathrm{d}} \text { subset of BCCs from sun-exposed areas; }{ }^{\mathrm{e}} \text { aggressive BCCs; }{ }^{\mathrm{f}} \text { non-aggressive BCCs; }{ }^{\mathrm{g}} 23 \text { sporadic } \\
\text { BCCs and } 19 \text { BCCs from patients with Gorlin Syndrome; }{ }^{\mathrm{h}} 94 \text { from non-X irradiated patients and } 102 \text { from } \\
\text { X-irradiated patients; }{ }^{*} \text { only genes with a mutation frequency higher than } 10 \% \text { have been reported. LOH, copy loss } \\
\text { of heterozygosity; na, not applicable. }\end{array}$} \\
\hline
\end{tabular}

Activating SMO mutations were found in $10-20 \%$ of sporadic BCCs and are mainly represented by missense changes affecting codon 535 [14,19,22,62]. Functional studies on the W535L variant demonstrated that it is a constitutively active mutant and significantly increases basal $\mathrm{HH}$ activity in the absence of $\mathrm{HH}$ ligand [62]. Recent studies revealed that up to $8 \%$ of BCCs carry loss of function SUFU variants, both missense and nonsense mutations, which are able to disrupt its binding to GLI, thus leading to constitutive pathway activation $[19,22,48]$. A higher frequency of SUFU mutations has been reported by Urman et al. [63], although it is considered as a likely passenger mutation. Finally, the homologue $\mathrm{PTCH} 2$ gene, which shows a $57 \%$ of similarity with $\mathrm{PTCH} 1$ and also serves as a receptor, has been found to carry mutations in a small number of sporadic BCC $[64,65]$.

\subsection{TP53 Gene}

The second most frequent event associated with BCC pathogenesis is the inactivation of the TP53 gene. The TP53 tumor suppressor gene is involved in cell cycle arrest and activation of programmed cell death [66,67]. As a guardian of the genome, TP53 is stabilized upon stress by phosphorylation and alters the expression of different sets of downstream target genes including those that cause cell cycle arrest [66-68]. In a mouse model investigating BCC pathogenesis, loss of TP53 has been shown to upregulate the activity of the $\mathrm{HH}$ pathway by increasing $S M O$ expression and rendering the mouse interfollicular keratinocytes receptive for X-ray induced BCCs [69].

Inactivating TP53 genetic alterations have been detected in 50\% of human cancers, including all skin carcinomas, which are believed to be a very early if not initial event in carcinogenesis $[70,71]$. In skin cancers, the majority of TP53 missense substitutions are located in the central DNA-binding core domain (codons 102-292) and include codons 177, 196, 245, 248, 278, and 282, producing a full-length protein with altered function [57-61,71]. Regarding BCC, non-synonymous mutations in the TP53 gene have been reported in about half of sporadic cases whereas $\mathrm{LOH}$ has been described with a much lower frequency in BCC as compared to other tumors as colon, lung, and bladder cancers [57-61] (Table 1). Hot spots occurring specifically in BCC have been found at codons 177, 196, and 245 [58,71]. Codon 177 seems to be specific for BCC since it is not frequently mutated in other malignancies. Little is known about this codon but it is interesting to note that it includes a sequence slowly repaired 
after UV-irradiation [72]. Both codons 196 and 245 have been found to be mutated in breast and colon cancers. Codon 245 seems to play a major role in carcinogenesis being implicated in several tumor types, such as lung, head and neck, ovary, stomach, and esophagus malignancies [58,71].

The majority of TP53 mutations in BCC are C to T transitions, with a high frequency of CC to TT double base changes, clearly indicative of UV-induced changes [17,57,58,72]. A lower level of TP53 mutations were indeed identified in BCCs from sunscreen users compared to that of non-sunscreen users [59].

\section{Novel BCC-Associated Genes}

Recent improvements in technologies for genomic analysis have led to the identification of new driver genes for BCC, featuring a more complex genetic network of cancer-associated genes than previously hypothesized. It is noteworthy that there are discrepancies regarding the list of driver genes identified across the different studies, probably reflecting the clinico-pathological heterogeneity of analyzed BCCs, e.g., BCCs with a low risk or a high risk of recurrence, tumors from Gorlin syndrome patients, or BCCs naïve or resistant to target therapy $[19,22,26,48]$.

\subsection{Hippo-YAP Signaling Genes}

The Hippo pathway is crucial in organ size control, and its deregulation contributes to tumorigenesis (Figure 2). This pathway was initially investigated in Drosophila, in which mosaic mutations of Hippo-related genes resulted in tissue overgrowth [73,74]. The Hippo axis includes a series of kinases that, through a cascade of phosphorylation events, inactivate the transcriptional co-activator Yes-associated protein (YAP), thus regulating cell proliferation and apoptosis [75]. The YAP1 protein is the major downstream effector of the Hippo pathway [74] and the kinases MST1/2 and LATS1/2 represent the core component of the mammalian Hippo signaling. MST1/2 phosphorylate and activate LATS1/2 kinases, preventing the translocation of YAP1 and its family member TAZ (trascriptional co-activator with PDZ-binding motif) into the nucleus [75,76]. YAP1 transactivation may be inhibited by the non-receptor tyrosine phosphatase 14 (PTPN14) that promotes its nucleus-to-cytoplasm translocation through LATS1 activation $[77,78]$.

Many components of the Hippo-YAP cascade have been found to be deregulated in human cancers $[75,79,80]$, and, more recently, also in BCC. Genetic studies in mouse models showed that this pathway acts in balancing cutaneous growth and differentiation [81] and that elevated nuclear YAP1 levels lead to massive expansion of proliferative basal epidermal cells [80].

Aberrant LATS1 and PTPN14 function may represent an independent mechanism for activation of Hippo-YAP pathway. LATS1 gene has been investigated in only one study reporting inactivating mutations in 47 of $293(16 \%)$ BCCs, with $24 \%$ of the mutations being truncating, consistent with the tumor suppressor role of LATS1 [22]. The most frequent mutation was the R995C, occurring in the core of the kinase domain. Interestingly, in a previous case report, a Japanese patient with Gorlin syndrome was shown to carry a biallelic inactivation of LATS1 in an infiltrative BCC [82]. In addition to LATS1 mutations, missense mutations in the LATS2 gene, a paralog of LATS1, were reported in $12 \%$ of BCCs and in the PTPN14 gene in $23 \%$ of BCCs with $61 \%$ truncating changes [22]. In line with the identification of LATS1 and PTPN14 mutations, RNA sequencing studies showed that the Hippo-YAP pathway is significantly upregulated in BCC [22]. 


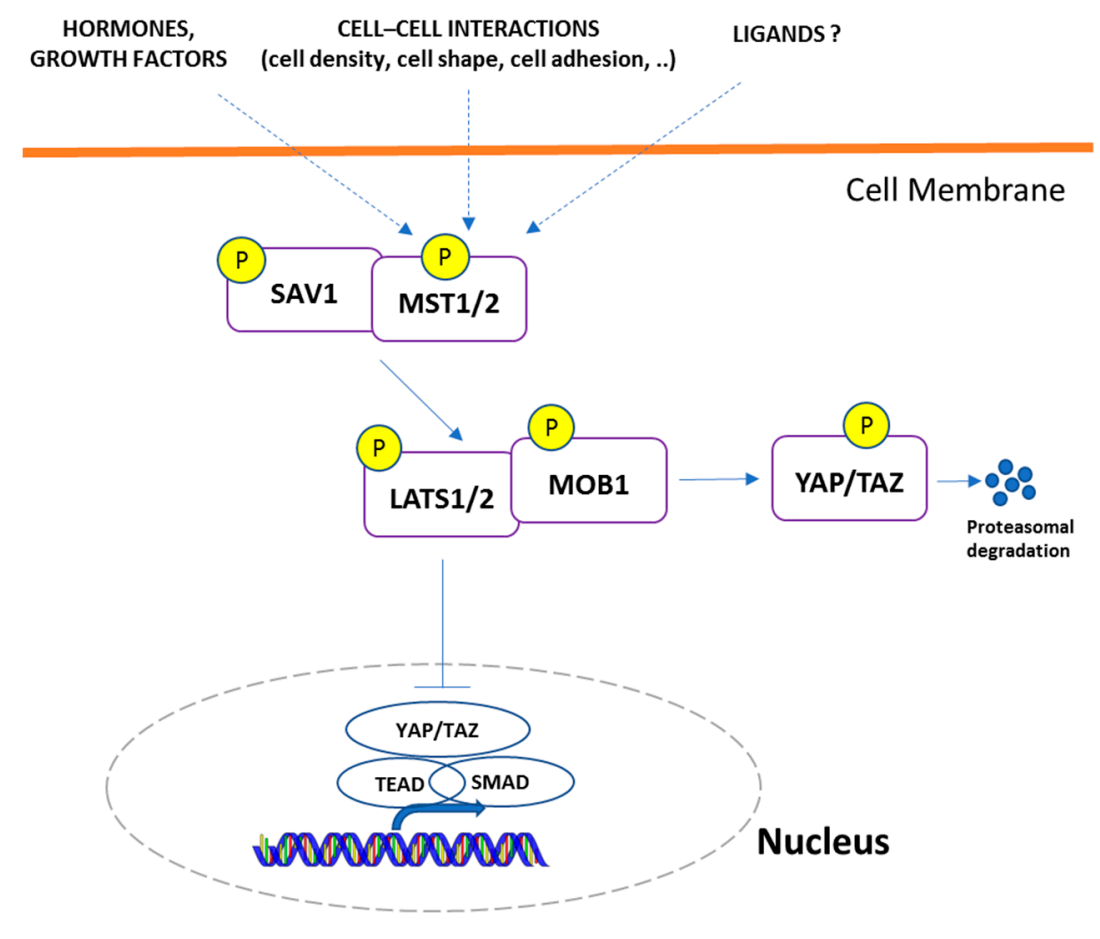

Figure 2. Hippo-YAP pathway. When the Hippo pathway is activated, MST1/2 kinases and SAV1 form a complex to phosphorylate and activate LATS1/2 and MOB1. Activated LATS1/2 phosphorylates YAP/TAZ, that is sequestered in the cytoplasm or degraded. Dephosphorylation of YAP/TAZ allows its traslocation into the nucleus and the interaction with TEAD1-4 to induce the expression of genes promoting tumor progression. MST, mammalian Ste2-like kinases Hpo orthologs; SAV, Protein Salvador Homolog 1; LATS, Large Tumor Suppressor Kinase Wts orthologs; MOB1, Mob-as-tumor-suppressor homologs; YAP, Yes Associated Protein Yki ortholog; TEAD, transcriptional enhancer associate domain; TAZ, transcriptional co-activator with PDZ-binding motif; SMAD, Mothers against decapentaplegic homolog.

\subsection{MYCN/FBXW7 Signaling}

MYCN is a member of the MYC family of transcriptional activators and a potential downstream effector of the HH pathway [83]. Changes in the levels of MYC family transcription factors profoundly influence cell growth, proliferation, differentiation, and apoptosis [84]. MYCN missense mutations have been identified in $30 \%$ of BCCs [22], with most of the mutations mapping in the region encoding the MYC box 1 domain, which is involved in the interaction with FBXW7 tumor suppressor [22]. FBXW7 is a component of the SCFFbw7 ubiquitin ligase that promotes proteasome-dependent MYC degradation through the ubiquitin pathway [84]. Functional studies demonstrated that four of the most frequent N-MYC substitutions found in BCC, T58A, P59L, P60L, and P63L impaired the binding with the FBXW7, resulting in excessive amounts of the N-MYC protein [22]. Aberrant copy-gain rarely occurs in BCC, while gene amplification is the main mechanism of pathogenic up-regulation of MYCN in medulloblastoma and neuroblastoma $[22,83,85]$. Interestingly, deleterious mutations and $\mathrm{LOH}$ events in the $F B X W 7$ gene occur in $5 \%$ and $8 \%$ of BCCs samples, respectively, suggesting a selective pressure for enhanced N-MYC stability in BCC [22].

\subsection{TERT-Promoter}

TERT gene encodes the catalytic reverse transcriptase subunit of telomerase that maintains telomere length. Increased telomerase activity is perceived to be one of the hallmarks of human cancers, and the transcriptional regulation of the TERT gene is the major cause of its cancer-specific activation [86]. 
The TERT gene is located on chromosome 5p15.33 and the promoter region of this gene is considered the most important regulatory element for telomerase expression (Figure 3). The core promoter region consists of 260 base pairs with several binding sites for transcription-factor that regulate gene transcription [87]. TERT promoter mutations have been detected at a high frequency in many different cancers as melanoma, non-melanoma skin cancers, bladder cancer, and glioma. They have been related to increased TERT expression through de novo creation of binding sites for Ets/TCF transcription factors, higher telomere length, and with markers of poor outcome [86,88]. The high recurrence, specificity, and gain of function of non-coding promoter TERT mutations support that they are driver rather than passenger events in cancer development [89].

\section{Nucleus}

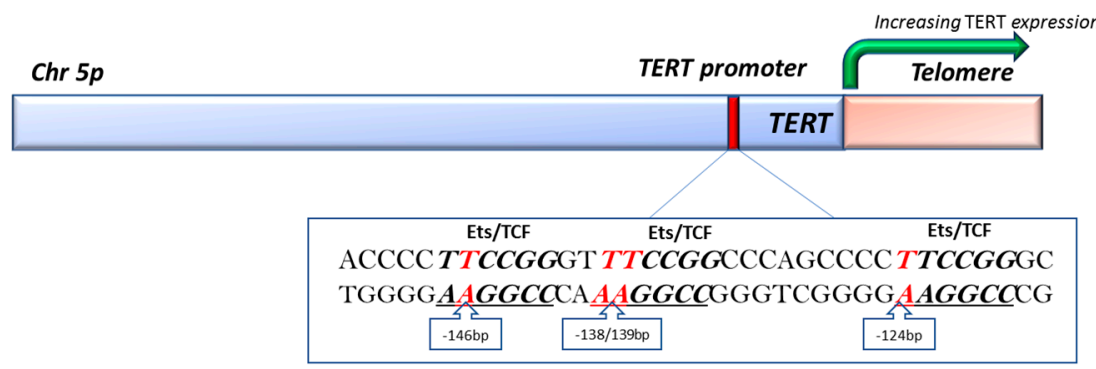

Figure 3. Schematic representation of TERT promoter structure. TERT promoter region (red bar) and $T E R T$ gene (pink bar). Core consensus sequence with Ets/TCF regulatory elements of TERT promoter and location of BCC-specific mutations (red) are reported in the box. The Ets/TCF binding motifs for Ets/TCF transcription factors created by mutations are underlined. TERT, telomerase reverse transcriptase; Ets/TCF; Ternary complex factor (TCF) subgroup of the Ets E26 transformation-specific transcription factor.

The discovery paper reported a disease-segregating causal germline mutation in a large melanoma family at $-57 \mathrm{bp}$ position from the ATG start site and recurrent somatic mutations at -124 and $-146 \mathrm{bp}$ positions in tumors from unrelated patients [90] (Figure 3). A few studies have recently investigated TERT promoter in BCC tumors, identifying a high prevalence of mutations. Most of TERT promoter mutations exhibit an UV-signature with $\mathrm{C}>\mathrm{T}$ or $\mathrm{CC}>\mathrm{TT}$ changes, again supporting an etiologic role for UV exposure [23-25].

\subsection{DPH3-OXNAD1 Bidirectional Promoter}

Similar to TERT, recurrent mutations in noncoding positions close to the transcription start site have been reported in the bidirectional promoter of both $D P H 3$ and oxidoreductase NAD-binding domain containing 1 (OXNAD1) genes. DPH3 is required for the synthesis of diphthamide, a modified histidine residue in eukaryotic translation elongation factor 2 that helps in the maintenance of translation fidelity. DPH3 silencing impairs in vivo metastasis in mouse melanoma cells, and its family member DPH1, which is also required for diphthamide synthesis, has been attributed a tumor-suppressor role [91].

Mutations in the bidirectional promoter region of DPH3-OXNAD1 (called DPH3 promoter) were first described in melanoma in two whole genome screenings for mutations in the regulatory regions of the genome [92,93]. The reported frequency of DPH3 mutations in melanoma was $16 \%(6 / 38)$ and $29.4 \%[92,93]$. Typical UV signature mutations of the DPH3 promoter were recently shown to be common in BCC (42\%) and squamous cell carcinoma (39\%) [26]. Mutations occurred at sites adjacent and within a binding motif for the Ets/TCF transcription factor, at -8 and -9 bp from $D P H 3$ transcription start site. Reporter assays carried out in one melanoma cell line for DPH3 and OXNAD1 orientations 
showed statistically significant, increased promoter activity due to $-8 /-9$ CC $>$ TT tandem mutations, although no effect was observed on DPH3 and OXNAD1 transcription in tumors [26].

\subsection{Other Potential BCC-Associated Genes}

A high frequency of mutations significantly associated with BCC tumorigenesis was observed in two cancer-related genes, PPP6C and STK19, in a recent study, including a large cohort of tumors [22]. PPP6C regulates cell cycle progression in human cells through control of cyclin D1 and inactivation of RB1 and participates to LATS1 activation [94,95]. Mutations were detected in $15 \%$ of BCC, with the most frequent being the R264C substitution, shown to impair the phosphatase activity of the encoded protein [96]. The STK19 gene encodes a kinase with an unknown function probably involved in transcriptional regulation and was found to be mutated in $10 \%$ of BCC tumors across the entire length of the gene. The most recurrent change was the D89N substitution, a mutation previously described in $5 \%$ of melanomas [97].

Other candidate cancer genes were found to be frequently mutated in BCC (Table 1), including ARID1A, CASP8, CSMD1, GRIN2A, KRAS, NOTCH1, NOTCH2, NRAS, PIK3CA, PREX2, and RAC1, although they did not show a statistically significant association with BCC [19,22]. Among them, two independent exome-sequencing studies $[19,22]$ reported a high frequency of mutations in NOTCH1 ( $29 \%$ and $50 \%$, respectively) and $\mathrm{NOTCH} 2$ ( $26 \%$ and $67 \%$, respectively) genes, mostly relating to loss of function, thus suggesting their tumor-suppressor role in BCC. Missense and truncating mutations in both genes have been detected across the entire length of the genes, without any evidence of hot-spot changes.

\section{Molecular Therapy}

The identification of tumor-specific genetic alterations is currently one of the most active areas of cancer research and is having a major impact on the development of novel therapies targeting known deregulated signaling pathways.

Aberrant activation of the $\mathrm{HH}$ pathway is the key molecular alteration in BCC growth and progression; thus, recent research has focused on developing therapeutic strategies targeting this signaling cascade. Two HH pathway inhibitors, viSMOdegib and sonidegib, both targeting the SMO protein, are currently FDA- and EMA-approved for treatment of advanced BCC. Other SMO inhibitors, as LY3039478 (Taledigib), IPI-926 (saridegib), and PF-04449913 (glasdegib), are currently being investigated in clinical trials in advanced solid tumors, including BCC [98-100]. The majority of BCC patients treated with the SMO inhibitors experience clinical benefits [101-103], although acquired resistance has been reported [104-106]. Resistance occurs predominantly through de novo mutations of the drug target SMO and, to a lesser extent, through concurrent copy number changes in SUFU and GLI2 [107] or upregulation of synergistic signals such as PI3K pathway [108]. For patients with acquired resistance to $S M O$ inhibitors, possible solutions may include pharmacological targeting of effectors downstream of $S M O$ or combination strategies with other molecular targeted therapies (e.g., PI3K, EGFR inhibitors) [106].

Small molecules targeting the GLI transcription factors, defined as GLI antagonists, are an emerging cancer therapy currently under investigation in preclinical studies and might be effective in tumors with canonical and non-canonical activation of $\mathrm{HH}$ pathway [106]. Verteporfin, a second-generation photosensitizer approved by the FDA for the treatment of age-related macular degeneration, has been shown to inhibit the proliferation of hepatocellular carcinoma and retinoblastoma cells by inhibiting the YAP pathway $[109,110]$. Bakshi et al. [111] are currently investigating the effects of verteprofin administered as monotherapy and in combination with SMO inhibitors in BCC tumor regression.

Monoclonal antibodies that block immune checkpoint proteins, as anti- programmed cell death-1 (PD-1) and PD-Ligand-1 (PD-L1), thus enhancing the anti-tumor immune response, have demonstrated remarkable efficacy against multiple cancers, including melanoma [111]. Several immune-related markers have been implicated in BCC pathogenesis [112-117], suggesting that immunotherapy may 
be a valuable therapeutic option for this tumor. Recently published case reports provide evidence for the efficacy of anti-PD-1 therapy in patients with advanced BCC, either as initial treatment or after acquired resistance to $\mathrm{HH}$ pathway inhibition [118-120]. In addition, a phase I clinical trial is currently investigating if pembrolizumab (anti-PD1) can be used with or without vismodegib to treat metastatic or unresectable BCCs (NCT02690948) [111].

\section{Conclusions}

Aberrant activation of the $\mathrm{HH}$ pathway is the hallmark of BCC carcinogenesis, with the majority of BCCs harboring PTCH1 and, less frequently, SMO mutations. Recent genomic studies discovered additional signaling pathways associated with the development of BCCs. The identification of inactivating mutations in two key components of the Hippo-YAP pathway, LATS1 and PTPN14 genes, provides clear evidence of the involvement of this signaling cascade in BCC, adding BCC to the broad group of human cancers with a deregulated Hippo-YAP axis. In addition, three candidate genes, MYCN, PPP6C, and STK19, known to be associated with melanoma development, might be considered as new BCC driver genes. Of note, emerging reports are showing that somatic, non-coding mutations within promoter regions of TERT and DPH3-OXNAD1 genes are common in all types of skin cancer, including BCC. All these evidences demonstrate a complex genetic network of cancer-related genes and different pathways contributing to BCC carcinogenesis, supporting a heterogeneous genetic origin. Understanding the molecular genetics of BCC tumorigenesis might have a major impact on the development of novel target therapies to be used as single agent or in combination, allowing us to enhance treatment efficacy and overcome tumor resistance.

BCC tumors display great variability in morphology, aggressiveness, and response to treatment, and there is an ongoing debate about whether the clinico-pathological heterogeneity of BCC is related to distinct molecular subtypes. The integration of molecular genetic findings with the clinico-pathological features of the tumors might lead to a better BCC classification that definitely will change diagnostic and treatment algorithms.

Author Contributions: Cristina Pellegrini and Maria Giovanna Maturo studied references and wrote manuscript; Lucia Di Nardo, Valeria Ciciarelli, and Carlota Gutiérrez García-Rodrigo proofread and organized the manuscript; Maria Concetta Fargnoli provided conceptualization and supervision and proofread the manuscript. All authors reviewed the final version of the manuscript.

Conflicts of Interest: The authors declare no conflicts of interest.

\section{References}

1. Puig, S.; Berrocal, A. Management of high-risk and advanced basal cell carcinoma. Clin. Transl. Oncol. 2015, 17, 497-503. [CrossRef] [PubMed]

2. Verkouteren, J.A.C.; Ramdas, K.H.R.; Wakkee, M.; Nijsten, T. Epidemiology of basal cell carcinoma: Scholarly review. Br. J. Dermatol. 2017, 177, 359-372. [CrossRef] [PubMed]

3. Flohil, S.C.; Seubring, I.; van Rossum, M.M.; Coebergh, J.W.; de Vries, E.; Nijsten, T. Trends in basal cell carcinoma incidence rates: A 37-year Dutch observational study. J. Investig. Dermatol. 2013, 133, 913-918. [CrossRef] [PubMed]

4. Deady, S.; Sharp, L.; Comber, H. Increasing skin cancer incidence in young; affluent; urban populations: A challenge for prevention. Br. J. Dermatol. 2014, 171, 324-331. [CrossRef] [PubMed]

5. Rubin, A.I.; Chen, E.H.; Ratner, D. Basal-cell carcinoma. N. Engl. J. Med. 2005, 353, 2262-2269. [CrossRef] [PubMed]

6. White, J.C. Multiple benign cystic epitheliomas. J. Cutan. Genitourin. Dis. 1894, 12, 477-484.

7. Jarisch, W. On the doctrine of skin tumors. Arch. Dermatol. Syphilol. 1894, 18, 162-222.

8. Gorlin, R.J.; Goltz, R.W. Multiple nevoid basal cell epithelioma; jaw cysts and bifid rib: A syndrome. N. Engl. J. Med. 1960, 262, 908-912. [CrossRef] [PubMed] 
9. Gailani, M.R.; Bale, S.J.; Leffell, D.J.; Di Giovanna, J.J.; Peck, G.L.; Poliak, S.; Drum, M.A.; Pastakia, B.; McBride, O.W.; Kase, R.; et al. Developmental defects in Gorlin syndrome related to a putative tumor suppressor gene on chromosome 9. Cell 1992, 69, 111-117. [CrossRef]

10. Hahn, H.; Wicking, C.; Zaphiropoulous, P.G. Mutations of the human homolog of Drosophila patched in the nevoid basal cell carcinoma syndrome. Cell 1996, 85, 841-851. [CrossRef]

11. Johnson, R.L.; Rothman, A.L.; Xie, J.; Goodrich, L.V.; Bare, J.W.; Bonifas, J.M.; Quinn, A.G.; Myers, R.M.; Cox, D.R.; Epstein, E.H., Jr.; et al. Human homolog of patched, a candidate gene for the basal cell nevus syndrome. Science 1996, 272, 1668-1671. [CrossRef] [PubMed]

12. Gailani, M.R.; Ståhle-Bäckdahl, M.; Leffell, D.J.; Glynn, M.; Zaphiropoulos, P.G.; Pressman, C.; Undén, A.B.; Dean, M.; Brash, D.E.; Bale, A.E.; et al. The role of the human homologue of Drosophila patched in sporadic basal cell carcinomas. Nat. Genet. 1996, 14, 78-81. [CrossRef] [PubMed]

13. Dahmane, N.; Lee, J.; Robins, P.; Heller, P.; Ruiz i Altaba, A. Activation of the transcription factor Gli1 and the Sonic hedgehog signalling pathway in skin tumours. Nature 1997, 389, 876-881. [CrossRef] [PubMed]

14. Xie, J.; Murone, M.; Luoh, S.M.; Ryan, A.; Gu, Q.; Zhang, C.; Bonifas, J.M.; Lam, C.W.; Hynes, M.; Goddard, A.; et al. Activating Smoothened mutations in sporadic basal-cell carcinoma. Nature 1998, 391, 90-92. [CrossRef] [PubMed]

15. Aszterbaum, M.; Rothman, A.; Johnson, R.L.; Fisher, M.; Xie, J.; Bonifas, J.M.; Zhang, X.; Scott, M.P.; Epstein, E.H., Jr. Identification of mutations in the human PATCHED gene in sporadic basal cell carcinomas and in patients with the basal cell nevus syndrome. J. Investig. Dermatol. 1998, 11, 885-888. [CrossRef] [PubMed]

16. Epstein, E.H. Basal cell carcinomas: Attack of the hedgehog. Nat. Rev. Cancer 2008, 8, 743-754. [CrossRef] [PubMed]

17. Zhang, H.; Ping, X.L.; Lee, P.K.; Wu, X.L.; Yao, Y.J.; Zhang, M.J.; Silvers, D.N.; Ratner, D.; Malhotra, R.; Peacocke, M.; et al. Role of PTCH and p53 genes in early-onset basal cell carcinoma. Am. J. Pathol. 2001, 158, 381-385. [CrossRef]

18. Kim, M.Y.; Park, H.J.; Baek, S.C.; Byun, D.G.; Houh, D. Mutations of the p53 and PTCH gene in basal cell carcinomas: UV mutation signature and strand bias. J. Dermatol. Sci. 2002, 29, 1-9. [CrossRef]

19. Jayaraman, S.S.; Rayhan, D.J.; Hazany, S.; Kolodney, M.S. Mutational landscape of basal cell carcinomas by whole-exome sequencing. J. Investig. Dermatol. 2014, 134, 213-220. [CrossRef] [PubMed]

20. Van der Schroeff, J.G.; Evers, L.M.; Boot, A.J.; Bos, J.L. Ras oncogene mutations in basal cell carcinomas and squamous cell carcinomas of human skin. J. Investig. Dermatol. 1990, 94, 423-425. [CrossRef] [PubMed]

21. Pierceall, W.E.; Goldberg, L.H.; Tainsky, M.A.; Mukhopadhyay, T.; Ananthaswamy, H.N. Ras gene mutation and amplification in human nonmelanoma skin cancers. Mol. Carcinog. 1991, 4, 196-202. [CrossRef] [PubMed]

22. Bonilla, X.; Parmentier, L.; King, B.; Bezrukov, F.; Kaya, G.; Zoete, V.; Seplyarskiy, V.B.; Sharpe, H.J.; McKee, T.; Letourneau, A.; et al. Genomic analysis identifies new drivers and progression pathways in skin basal cell carcinoma. Nat. Genet. 2016, 48, 398-406. [CrossRef] [PubMed]

23. Griewank, K.G.; Murali, R.; Schilling, B.; Schimming, T.; Möller, I.; Moll, I.; Schwamborn, M.; Sucker, A.; Zimmer, L.; Schadendorf, D.; et al. TERT promoter mutations are frequent in cutaneous basal cell carcinoma and squamous cell carcinoma. PLoS ONE 2013, 8, e80354. [CrossRef] [PubMed]

24. Scott, G.A.; Laughlin, T.S.; Rothberg, P.G. Mutations of the TERT promoter are common in basal cell carcinoma and squamous cell carcinoma. Mod. Pathol. 2014, 27, 516-523. [CrossRef] [PubMed]

25. Pópulo, H.; Boaventura, P.; Vinagre, J.; Batista, R.; Mendes, A.; Caldas, R.; Pardal, J.; Azevedo, F.; Honavar, M.; Guimarães, I.; et al. TERT promoter mutations in skin cancer: The effects of sun exposure and X-irradiation. J. Investig. Dermatol. 2014, 134, 2251-2257. [CrossRef] [PubMed]

26. Denisova, E.; Heidenreich, B.; Nagore, E.; Rachakonda, P.S.; Hosen, I.; Akrap, I.; Traves, V.; García-Casado, Z.; López-Guerrero, J.A.; Requena, C.; et al. Frequent DPH3 promoter mutations in skin cancers. Oncotarget 2015, 6, 35922-35930. [PubMed]

27. Ikehata, H.; Ono, T. The mechanisms of UV mutagenesis. J. Radiat. Res. 2011, 52, 115-125. [CrossRef] [PubMed]

28. Yamamoto, J.; Plaza, P.; Brettel, K. Repair of (6-4) Lesions in DNA by (6-4) Photolyase: 20 Years of Quest for the Photoreaction Mechanism. Photochem. Photobiol. 2017, 93, 51-66. [CrossRef] [PubMed] 
29. Hussein, M.R. Ultraviolet radiation and skin cancer: Molecular mechanisms. J. Cutan. Pathol. 2005, 32, 191-205. [CrossRef] [PubMed]

30. Daya-Grosjean, L.; Couvé-Privat, S. Sonic hedgehog signaling in basal cell carcinomas. Cancer Lett. 2005, 225, 181-192. [CrossRef] [PubMed]

31. Justilien, V.; Fields, A.P. Molecular pathways: Novel approaches for improved therapeutic targeting of Hedgehog signaling in cancer stem cells. Clin. Cancer Res. 2015, 21, 505-513. [CrossRef] [PubMed]

32. Briscoe, J.; Therond, P.P. The mechanisms of Hedgehog signalling and its roles in development and disease. Nat. Rev. Mol. Cell Biol. 2013, 14, 416-429. [CrossRef] [PubMed]

33. Bangs, F.; Anderson, K.V. Primary Cilia and Mammalian Hedgehog Signaling. Cold Spring Harb. Perspect. Biol. 2017, 9, a028175. [CrossRef] [PubMed]

34. Otsuka, A.; Levesque, M.P.; Dummer, R.; Kabashima, K. Hedgehog signaling in basal cell carcinoma. J. Dermatol. Sci. 2015, 78, 95-100. [CrossRef] [PubMed]

35. Rohatgi, R.; Milenkovic, L.; Scott, M.P. Patched1 regulates hedgehog signaling at the primary cilium. Science 2007, 317, 372-376. [CrossRef] [PubMed]

36. Katoh, Y.; Katoh, M. Hedgehog target genes: Mechanisms of carcinogenesis induced by aberrant hedgehog signaling activation. Curr. Mol. Med. 2009, 9, 873-886. [CrossRef] [PubMed]

37. Seto, M.; Ohta, M.; Asaoka, Y.; Ikenoue, T.; Tada, M.; Miyabayashi, K.; Mohri, D.; Tanaka, Y.; Ijichi, H.; Tateishi, K.; et al. Regulation of the hedgehog signaling by the mitogen-activated protein kinase cascade in gastric cancer. Mol. Carcinog. 2009, 48, 703-712. [CrossRef] [PubMed]

38. Rajurkar, M.; De Jesus-Monge, W.E.; Driscoll, D.R.; Appleman, V.A.; Huang, H.; Cotton, J.L.; Klimstra, D.S.; Zhu, L.J.; Simin, K.; Xu, L.; et al. The activity of GLI transcription factors is essential for Kras-induced pancreatic tumorigenesis. Proc. Natl. Acad. Sci. USA 2012, 109, E1038-E1047. [CrossRef] [PubMed]

39. Ramaswamy, B.; Lu, Y.; Teng, K.Y.; Nuovo, G.; Li, X.; Shapiro, C.L.; Majumder, S. Hedgehog signaling is a novel therapeutic target in tamoxifen-resistant breast cancer aberrantly activated by PI3K/AKT pathway. Cancer Res. 2012, 72, 5048-5059. [CrossRef] [PubMed]

40. Deng, W.T.; Vanderbilt, D.B.; Lin, C.C.; Martin, K.H.; Brundage, K.M.; Ruppert, J.M. SOX9 inhibits beta-TrCP-mediated protein degradation to promote nuclear GLI1 expression and cancer stem cell properties. J. Cell Sci. 2015, 128, 1123-1138. [CrossRef] [PubMed]

41. Ke, Z.; Caiping, S.; Qing, Z.; Xiaojing, W. Sonic hedgehog-GLI1 signals promote epithelial-mesenchymal transition in ovarian cancer by mediating PI3K/AKT pathway. Med. Oncol. 2015, 32, 368. [CrossRef] [PubMed]

42. Zhou, J.; Zhu, G.; Huang, J.; Li, L.; Du, Y.; Gao, Y.; Wu, D.; Wang, X.; Hsieh, J.T.; He, D.; et al. Non-canonical GLI1/2 activation by PI3K/AKT signaling in renal cell carcinoma: A novel potential therapeutic target. Cancer Lett. 2016, 370, 313-323. [CrossRef] [PubMed]

43. Rimkus, T.K.; Carpenter, R.L.; Qasem, S.; Chan, M.; Lo, H.W. Targeting the Sonic Hedgehog Signaling Pathway: Review of Smoothened and GLI Inhibitors. Cancers 2016, 8, 22. [CrossRef] [PubMed]

44. Makinodan, E.; Marneros, A.G. Protein kinase a activation inhibits oncogenic sonic hedgehog signalling and suppresses basal cell carcinoma of the skin. Exp. Dermatol. 2012, 21, 847-852. [CrossRef] [PubMed]

45. Sheng, T.; Chi, S.; Zhang, X.; Xie, J. Regulation of GLI1 localization by the camp/protein kinase a signaling axis through a site near the nuclear localization signal. J. Biol. Chem. 2006, 281, 9-12. [CrossRef] [PubMed]

46. Stecca, B.; Ruiz i Altaba, A. A GLI1-p53 inhibitory loop controls neural stem cell and tumour cell numbers. EMBO J. 2009, 28, 663-676. [CrossRef] [PubMed]

47. Athar, M.; Li, C.; Kim, A.L.; Spiegelman, V.S.; Bickers, D.R. Sonic hedgehog signaling in Basal cell nevus syndrome. Cancer Res. 2014, 74, 4967-4975. [CrossRef] [PubMed]

48. Reifenberger, J.; Wolter, M.; Knobbe, C.B.; Köhler, B.; Schönicke, A.; Scharwächter, C.; Kumar, K.; Blaschke, B.; Ruzicka, T.; Reifenberger, G. Somatic mutations in the PTCH; SMOH; SUFUH and TP53 genes in sporadic basal cell carcinomas. Br. J. Dermatol. 2005, 152, 43-51. [CrossRef] [PubMed]

49. Teh, M.T.; Blaydon, D.; Chaplin, T.; Foot, N.J.; Skoulakis, S.; Raghavan, M.; Harwood, C.A.; Proby, C.M.; Philpott, M.P.; Young, B.D.; et al. Genomewide single nucleotide polymorphism microarray mapping in basal cell carcinomas unveils uniparental disomy as a key somatic event. Cancer Res. 2005, 65, 8597-8603. [CrossRef] [PubMed] 
50. Santos, D.C.; Zaphiropoulos, P.G.; Neto, C.F.; Pimentel, E.R.; Sanches, J.A., Jr.; Ruiz, I.R. PTCH1 gene mutations in exon 17 and loss of heterozygosity on D9S180 microsatellite in sporadic and inherited human basal cell carcinomas. Int. J. Dermatol. 2011, 50, 838-843. [CrossRef] [PubMed]

51. Gailani, M.R.; Leffell, D.J.; Ziegler, A.; Gross, E.G.; Brash, D.E.; Bale, A.E. Relationship between sunlight exposure and a key genetic alteration in basal cell carcinoma. J. Natl. Cancer Inst. 1996, 88, 349-354. [CrossRef] [PubMed]

52. Huang, Y.S.; Bu, D.F.; Li, X.Y.; Ma, Z.H.; Yang, Y.; Lin, Z.M.; Lu, F.M.; Tu, P.; Li, H. Unique features of PTCH1mutation spectrum in Chinese sporadic basal cellcarcinoma. J. Eur. Acad. Dermatol. Venereol. 2013, 27, 235-241. [CrossRef] [PubMed]

53. Lacour, J.P. Carcinogenesis of basal cell carcinomas: Genetics and molecular mechanisms. Br. J. Dermatol. 2002, 146 (Suppl. S61), 17-19. [CrossRef] [PubMed]

54. Daya-Grosjean, L.; Sarasin, A. UV-specific mutations of the human patched gene in basal cell carcinomas from normal individuals and xeroderma pigmentosum patients. Mutat. Res. 2000, 450, 193-199. [CrossRef]

55. Danaee, H.; Karagas, M.R.; Kelsey, K.T.; Perry, A.E.; Nelson, H.H. Allelic loss at Drosophila patched gene is highly prevalent in Basal and squamous cell carcinomas of the skin. J. Investig. Dermatol. 2006, 126, 1152-1158. [CrossRef] [PubMed]

56. Heitzer, E.; Lassacher, A.; Quehenberger, F.; Kerl, H.; Wolf, P. UV fingerprints predominate in the PTCH mutation spectra of basal cell carcinomas independent of clinical phenotype. J. Investig. Dermatol. 2007, 127, 2872-2881. [CrossRef] [PubMed]

57. Rady, P.; Scinicariello, F.; Wagner, R.F., Jr.; Tyring, S.K. p53 mutations in basal cell carcinomas. Cancer Res. 1992, 52, 3804-3806. [PubMed]

58. Ziegler, A.; Leffell, D.J.; Kunala, S.; Sharma, H.W.; Gailani, M.; Simon, J.A.; Halperin, A.J.; Baden, H.P.; Shapiro, P.E.; Bale, A.E. Mutation hotspots due to sunlight in the p53 gene of nonmelanoma skin cancers. Proc. Natl. Acad. Sci. USA 1993, 90, 4216-4220. [CrossRef] [PubMed]

59. Rosenstein, B.S.; Phelps, R.G.; Weinstock, M.A.; Bernstein, J.L.; Gordon, M.L.; Rudikoff, D.; Kantor, I.; Shelton, R.; Lebwohl, M.G. p53 mutations in basal cell carcinomas arising in routine users of sunscreens. Photochem. Photobiol. 1999, 70, 798-806. [CrossRef] [PubMed]

60. Bolshakov, S.; Walker, C.M.; Strom, S.S.; Selvan, M.S.; Clayman, G.L.; El-Naggar, A.; Lippman, S.M.; Kripke, M.L.; Ananthaswamy, H.N. p53 mutations in human aggressive and nonaggressive basal and squamous cell carcinomas. Clin. Cancer Res. 2003, 9, 228-324. [PubMed]

61. Wang, Y.M.; Huang, Y.S.; Ma, Z.H.; Bu, D.F.; Wang, Y.; Tu, P.; Li, H. Frequency and features of TP53 mutation in 30 Chinese patients with sporadic basal cell carcinoma. Clin. Exp. Dermatol. 2014, 39, 829-834. [CrossRef] [PubMed]

62. Atwood, S.X.; Sarin, K.Y.; Li, J.R.; Yao, C.Y.; Urman, N.M.; Chang, A.L.S.; Tang, J.Y.; Oro, A.E. Rolling the Genetic Dice: Neutral and Deleterious Smoothened Mutations in Drug-Resistant Basal Cell Carcinoma. J. Investig. Dermatol. 2015, 135, 2138-2141. [CrossRef] [PubMed]

63. Urman, N.M.; Mirza, A.; Atwood, S.X.; Whitson, R.J.; Sarin, K.Y.; Tang, J.Y.; Oro, A.E. Tumor-Derived Suppressor of Fused Mutations Reveal Hedgehog Pathway Interactions. PLoS ONE 2016, 11, e0168031. [CrossRef] [PubMed]

64. Smyth, I.; Narang, M.A.; Evans, T.; Heimann, C.; Nakamura, Y.; Chenevix-Trench, G.; Pietsch, T.; Wicking, C.; Wainwright, B.J. Isolation and characterization of human patched 2 (PTCH2), a putative tumour suppressor gene inbasal cell carcinoma and medulloblastoma on chromosome 1p32. Hum. Mol. Genet. 1999, 8, 291-297. [CrossRef] [PubMed]

65. De Zwaan, S.E.; Haass, N.K. Genetics of basal cell carcinoma. Australas. J. Dermatol. 2010, 51, 81-92. [CrossRef] [PubMed]

66. Lane, D.P. Cancer. p53; guardian of the genome. Nature 1992, 358, 15-16. [CrossRef] [PubMed]

67. Aubrey, B.J.; Strasser, A.; Kelly, G.L. Tumor-Suppressor Functions of the TP53 Pathway. Cold Spring Harb. Perspect. Med. 2016, 6, a026062. [CrossRef] [PubMed]

68. Boukamp, P. Non-melanoma skin cancer: What drives tumor development and progression? Carcinogenesis 2005, 26, 1657-1667. [CrossRef] [PubMed]

69. Wang, G.Y.; Wang, J.; Mancianti, M.L.; Epstein, E.H., Jr. Basal cell carcinomas arise from hair follicle stem cells in Ptch1(+/-) mice. Cancer Cell 2011, 19, 114-124. [CrossRef] [PubMed] 
70. Benjamin, C.L.; Ananthaswamy, H.N. p53 and the pathogenesis of skin cancer. Toxicol. Appl. Pharmacol. 2007, 224, 241-248. [CrossRef] [PubMed]

71. Giglia-Mari, G.; Sarasin, A. TP53 mutations in human skin cancers. Hum. Mutat. 2003, 21, 217-228. [CrossRef] [PubMed]

72. Tornaletti, S.; Pfeifer, G.P. Slow repair of pyrimidine dimers at p53 mutation hotspots in skin cancer. Science 1994, 263, 1436-1438. [CrossRef] [PubMed]

73. Yu, F.X.; Zhao, B.; Panupinthu, N.; Jewell, J.L.; Lian, I.; Wang, L.H.; Zhao, J.; Yuan, H.; Tumaneng, K.; Li, H.; et al. Regulation of the Hippo-YAP pathway by G-protein-coupled receptor signaling. Cell 2012, 150, 780-791. [CrossRef] [PubMed]

74. Zhao, B.; Li, L.; Lei, Q.; Guan, K.L. The Hippo-YAP pathway in organ size control and tumorigenesis: An updated version. Genes Dev. 2010, 24, 862-874. [CrossRef] [PubMed]

75. Michaloglou, C.; Lehmann, W.; Martin, T.; Delaunay, C.; Hueber, A.; Barys, L.; Niu, H.; Billy, E.; Wartmann, M.; Ito, M.; et al. The tyrosine phosphatase PTPN14 is a negative regulator of YAP activity. PLoS ONE 2013, 8, e61916. [CrossRef] [PubMed]

76. Hao, Y.; Chun, A.; Cheung, K.; Rashidi, B.; Yang, X. Tumor suppressor LATS1 is a negative regulator of oncogene YAP. J. Biol. Chem. 2008, 283, 5496-5509. [CrossRef] [PubMed]

77. Wang, W.; Huang, J.; Wang, X.; Yuan, J.; Li, X.; Feng, L.; Park, J.I.; Chen, J. PTPN14 is required for the density-dependent control of YAP1. Genes Dev. 2012, 26, 1959-1971. [CrossRef] [PubMed]

78. Wilson, K.E.; Li, Y.W.; Yang, N.; Shen, H.; Orillion, A.R.; Zhang, J. PTPN14 forms a complex with Kibra and LATS1 proteins and negatively regulates the YAP oncogenic function. J. Biol. Chem. 2014, 289, 23693-23700. [CrossRef] [PubMed]

79. Overholtzer, M.; Zhang, J.; Smolen, G.A.; Muir, B.; Li, W.; Sgroi, D.C.; Deng, C.X.; Brugge, J.S.; Haber, D.A. Transforming properties of YAP; a candidate oncogene on the chromosome 11q22 amplicon. Proc. Natl. Acad. Sci. USA 2006, 103, 12405-12410. [CrossRef] [PubMed]

80. Schlegelmilch, K.; Mohseni, M.; Kirak, O.; Pruszak, J.; Rodriguez, J.R.; Zhou, D.; Kreger, B.T.; Vasioukhin, V.; Avruch, J.; Brummelkamp, T.J.; et al. Yap1 acts downstream of alpha-catenin to control epidermal proliferation. Cell 2011, 144, 782-795. [CrossRef] [PubMed]

81. Zhang, H.; Pasolli, H.A.; Fuchs, E. Yes-associated protein (YAP) transcriptional coactivator functions in balancing growth and differentiation in skin. Proc. Natl. Acad. Sci. USA 2011, 108, 2270-2275. [CrossRef] [PubMed]

82. Tate, G.; Kishimoto, K.; Mitsuya, T. Biallelic alterations of the large tumor suppressor 1 (LATS1) gene in infiltrative; but not superficial; basal cell carcinomas in a Japanese patient with nevoid basal cell carcinoma syndrome. Med. Mol. Morphol. 2015, 48, 177-182. [CrossRef] [PubMed]

83. Hatton, B.A.; Knoepfler, P.S.; Kenney, A.M.; Rowitch, D.H.; de Alborán, I.M.; Olson, J.M.; Eisenman, R.N. $\mathrm{N}$-myc is an essential downstream effector of Shh signaling during both normal and neoplastic cerebellar growth. Cancer Res. 2006, 66, 8655-8661. [CrossRef] [PubMed]

84. Welcker, M.; Orian, A.; Jin, J.; Grim, J.E.; Harper, J.W.; Eisenman, R.N.; Clurman, B.E. The Fbw7 tumor suppressor regulates glycogen synthase kinase 3 phosphorylation-dependent c-Myc protein degradation. Proc. Natl. Acad. Sci. USA 2004, 101, 9085-9090. [CrossRef] [PubMed]

85. Freier, K.; Flechtenmacher, C.; Devens, F.; Hartschuh, W.; Hofele, C.; Lichter, P.; Joos, S. Recurrent NMYC copy number gain and high protein expression in basal cell carcinoma. Oncol. Rep. 2006, 15, 1141-1145. [CrossRef] [PubMed]

86. Rachakonda, P.S.; Hosen, I.; de Verdier, P.J.; Fallah, M.; Heidenreich, B.; Ryk, C.; Wiklund, N.P.; Steineck, G.; Schadendorf, D.; Heimminki, K.; et al. TERT promoter mutations in bladder cancer affect patient survival and disease recurrence through modification by a common polymorphism. Proc. Natl. Acad. Sci. USA 2013, 110, 17426-17431. [CrossRef] [PubMed]

87. Heidenreich, B.; Kumar, R. TERT promoter mutations in telomere biology. Mutat. Res. 2017, 771, 15-31. [CrossRef] [PubMed]

88. Heidenreich, B.; Rachakonda, P.S.; Hosen, I.; Volz, F.; Hemminki, K.; Weyerbrock, A.; Kumar, R. TERT promoter mutations and telomere length in adult malignant gliomas and recurrences. Oncotarget 2015, 6, 10617-10633. [CrossRef] [PubMed]

89. Heidenreich, B.; Rachakonda, P.S.; Hemminki, K.; Kumar, R. TERT promoter mutations in cancer development. Curr. Opin. Genet. Dev. 2014, 24, 30-37. [CrossRef] [PubMed] 
90. Horn, S.; Figl, A.; Rachakonda, P.S.; Fischer, C.; Sucker, A.; Gast, A.; Kadel, S.; Moll, I.; Nagore, E.; Hemminki, K.; et al. TERT promoter mutations in familial and sporadic melanoma. Science 2013, 339, 959-961. [CrossRef] [PubMed]

91. Wang, L.; Shi, Y.; Ju, P.; Liu, R.; Yeo, S.P.; Xia, Y.; Owlanj, H.; Feng, Z. Silencing of diphthamide synthesis 3 (Dph3) reduces metastasis of murine melanoma. PLoS ONE 2012, 7, e49988. [CrossRef] [PubMed]

92. Weinhold, N.; Jacobsen, A.; Schultz, N.; Sander, C.; Lee, W. Genome-wide analysis of noncoding regulatory mutations in cancer. Nat. Genet. 2014, 46, 1160-1165. [CrossRef] [PubMed]

93. Fredriksson, N.J.; Ny, L.; Nilsson, J.A.; Larsson, E. Systematic analysis of noncoding somatic mutations and gene expression alterations across 14 tumor types. Nat. Genet. 2014, 46, 1258-1263. [CrossRef] [PubMed]

94. Stefansson, B.; Brautigan, D.L. Protein phosphatase PP6 N terminal domain restricts G1 to S phase progression in human cancer cells. Cell Cycle 2007, 6, 1386-1392. [CrossRef] [PubMed]

95. Couzens, A.L.; Knight, J.D.; Kean, M.J.; Teo, G.; Weiss, A.; Dunham, W.H.; Lin, Z.Y.; Bagshaw, R.D.; Sicheri, F.; Pawson, T.; et al. Protein interaction network of the mammalian Hippo pathway reveals mechanisms of kinase-phosphatase interactions. Sci. Signal. 2013, 6, rs15. [CrossRef] [PubMed]

96. Hammond, D.; Zeng, K.; Espert, A.; Bastos, R.N.; Baron, R.D.; Gruneberg, U.; Barr, F.A. Melanoma-associated mutations in protein phosphatase 6 cause chromosome instability and DNA damage owing to dysregulated Aurora-A. J. Cell Sci. 2013, 126, 3429-3440. [CrossRef] [PubMed]

97. Hodis, E.; Watson, I.R.; Kryukov, G.V.; Arold, S.T.; Imielinski, M.; Theurillat, J.P.; Nickerson, E.; Auclair, D.; Li, L.; Place, C.; et al. A landscape of driver mutations in melanoma. Cell 2012, 150, 251-263. [CrossRef] [PubMed]

98. Jimeno, A.; Weiss, G.J.; Miller, W.H., Jr.; Gettinger, S.; Eigl, B.J.; Chang, A.L.; Dunbar, J.; Devens, S.; Faia, K.; Skliris, G.; et al. Phase I study of the Hedgehog pathway inhibitor IPI-926 in adult patients with solid tumors. Clin. Cancer Res. 2013, 19, 2766-2774. [CrossRef] [PubMed]

99. Wagner, A.J.; Messersmith, W.A.; Shaik, M.N.; Zheng, X.; McLachlan, K.R.; Cesari, R.; Courtney, R.; Levin, W.J.; El-Khoueiry, A.B. A phase I study of PF-04449913, an oral Hedgehog inhibitor, in patients with advanced solid tumors. Clin. Cancer Res. 2015, 21, 1044-1051. [CrossRef] [PubMed]

100. Amaral, T.; Garbe, C. Non-melanoma skin cancer: New and future synthetic drug treatments. Expert Opin. Pharmacother. 2017, 18, 689-699. [CrossRef] [PubMed]

101. Cucchi, D.; Occhione, M.A.; Gulino, A.; De Smaele, E. Hedgehog signaling pathway and its targets for treatment in basal cell carcinoma. J. Exp. Pharmacol. 2012, 4, 173-185. [PubMed]

102. Basset-Seguin, N.; Hauschild, A.; Grob, J.J.; Kunstfeld, R.; Dréno, B.; Mortier, L.; Ascierto, P.A.; Licitra, L.; Dutriaux, C.; Thomas, L.; et al. Vismodegib in patients with advanced basal cell carcinoma (STEVIE): A pre-planned interim analysis of an international; open-label trial. Lancet Oncol. 2015, 16, 729-736. [CrossRef]

103. Kish, T.; Corry, L. Sonidegib (Odomzo) for the Systemic Treatment of Adults with Recurrent, Locally Advanced Basal Cell Skin Cancer. Pharm. Ther. 2016, 41, 322-325.

104. Brinkhuizen, T.; Reinders, M.G.; Van Geel, M.; Hendriksen, A.J.; Paulussen, A.D.; Winnepenninckx, V.J.; Keymeulen, K.B.; Soetekouw, P.M.; van Steensel, M.A. Acquired resistance to the Hedgehog pathway inhibitor vismodegib due to smoothened mutations in treatment of locally advanced basal cell carcinoma. J. Am. Acad. Dermatol. 2014, 71, 1005-1008. [CrossRef] [PubMed]

105. Pricl, S.; Cortelazzi, B.; Dal Col, V.; Marson, D.; Laurini, E.; Fermeglia, M.; Licitra, L.; Pilotti, S.; Bossi, P.; Perrone, F. Smoothened (SMO) receptor mutations dictate resistance to vismodegib in basal cell carcinoma. Mol. Oncol. 2015, 9, 389-397. [CrossRef] [PubMed]

106. Gonnissen, A.; Isebaert, S.; Haustermans, K. Targeting the Hedgehog signaling pathway in cancer: Beyond Smoothened. Oncotarget 2015, 6, 13899-13913. [CrossRef] [PubMed]

107. Sharpe, H.J.; Pau, G.; Dijkgraaf, G.J.; Basset-Seguin, N.; Modrusan, Z.; Januario, T.; Tsui, V.; Durham, A.B.; Dlugosz, A.A.; Haverty, P.M.; et al. Genomic analysis of Smoothened inhibitor resistance in basal cell carcinoma. Cancer Cell 2015, 27, 327-341. [CrossRef] [PubMed]

108. Buonamici, S.; Williams, J.; Morrissey, M.; Wang, A.; Guo, R.; Vattay, A.; Hsiao, K.; Yuan, J.; Green, J.; Ospina, B.; et al. Interfering with resistance to smoothened antagonists by inhibition of the PI3K pathway in medulloblastoma. Sci. Transl. Med. 2010, 2, 51ra70. [CrossRef] [PubMed]

109. Liu-Chittenden, Y.; Huang, B.; Shim, J.S.; Chen, Q.; Lee, S.J.; Anders, R.A.; Liu, J.O.; Pan, D. Genetic and pharmaco-logical disruption of the TEAD-YAP complex suppresses the oncogenic activity of YAP. Genes Dev. 2012, 26, 1300-1305. [CrossRef] [PubMed] 
110. Brodowska, K.; Al-Moujahed, A.; Marmalidou, A.; Meyer Zu Horste, M.; Cichy, J.; Miller, J.W.; Gragoudas, E.; Vavvas, D.G. The clinically used photosensitizer Verteporfin (VP) inhibits YAP-TEAD andhuman retinoblastoma cell growth in vitro without light activation. Exp. Eye Res. 2014, 124, 67-73. [CrossRef] [PubMed]

111. Bakshi, A.; Chaudhary, S.C.; Rana, M.; Elmets, C.A.; Athar, M. Basal cell carcinoma pathogenesis and therapy involvinghedgehog signaling and beyond. Mol. Carcinog. 2017, 56, 2543-2557. [CrossRef] [PubMed]

112. Glaser, R.; Andridge, R.; Yang, E.V.; Shana'ah, A.Y.; Di Gregorio, M.; Chen, M.; Johnson, S.L.; De Renne, L.A.; Lambert, D.R.; Jewell, S.D.; et al. Tumor site immune markers associated with risk for subsequent basal cell carcinomas. PLoS ONE 2011, 6, e25160. [CrossRef] [PubMed]

113. Wong, D.A.; Bishop, G.A.; Lowes, M.A.; Cooke, B.; Barnetson, R.S.; Halliday, G.M. Cytokine profiles in spontaneously regressing basal cell carcinomas. Br. J. Dermatol. 2000, 143, 91-98. [CrossRef] [PubMed]

114. Kaporis, H.G.; Guttman-Yassky, E.; Lowes, M.A.; Haider, A.S.; Fuentes-Duculan, J.; Darabi, K.; Whynot-Ertelt, J.; Khatcherian, A.; Cardinale, I.; Novitskaya, I.; et al. Human basal cell carcinoma is associated with Foxp3+ T cells in a Th2 dominant microenvironment. J. Investig. Dermatol. 2007, 127, 2391-2398. [CrossRef] [PubMed]

115. Elamin, I.; Zecević, R.D.; Vojvodić, D.; Medenica, L.; Pavlović, M.D. Cytokine concentrations in basal cell carcinomas of different histological types and localization. Acta Dermatovenerol. Alp. Pannonica Adriat. 2008, 17, 55-59. [PubMed]

116. Pellegrini, C.; Orlandi, A.; Costanza, G.; Di Stefani, A.; Piccioni, A.; Di Cesare, A.; Chiricozzi, A.; Ferlosio, A.; Peris, K.; Fargnoli, M.C. Expression of IL-23/Th17-related cytokines in basal cell carcinoma and in the response to medical treatments. PLoS ONE 2017, 12, e0183415. [CrossRef] [PubMed]

117. Nardinocchi, L.; Sonego, G.; Passarelli, F.; Avitabile, S.; Scarponi, C.; Failla, C.M.; Simoni, S.; Albanesi, C.; Cavani, A. Interleukin-17 and interleukin-2 promote tumor progression in human nonmelanoma skin cancer. Eur. J. Immunol. 2015, 45, 922-931. [CrossRef] [PubMed]

118. Falchook, G.S.; Leidner, R.; Stankevich, E.; Piening, B.; Bifulco, C.; Lowy, I.; Fury, M.G. Responses of metastatic basal cell and cutaneous squamous cell carcinomas to anti-PD1 monoclonal antibody REGN2810. J. Immunother. Cancer 2016, 4, 70. [CrossRef] [PubMed]

119. Hauschild, A.; Eichstaedt, J.; Möbus, L.; Kähler, K.; Weichenthal, M.; Schwarz, T.; Weidinger, S. Regression of melanoma metastases and multiple non-melanoma skin cancers in xeroderma pigmentosum by the PD1-antibody pembrolizumab. Eur. J. Cancer 2017, 77, 84-87. [CrossRef] [PubMed]

120. Lipson, E.J.; Lilo, M.T.; Ogurtsova, A.; Esandrio, J.; Xu, H.; Brothers, P.; Schollenberger, M.; Sharfman, W.H.; Taube, J.M. Basal cell carcinoma: PD-L1/PD-1 checkpoint expression and tumor regression after PD-1 blockade. J. Immunother. Cancer 2017, 5, 23. [CrossRef] [PubMed] 